6. Кузин А.Н., Петров В.И. Мелиорация деградированных пастбищ Северо-Западного Прикаспия саванными насаждениями / / Охрана почв Калмыкии: сб. науч. тр. - Элиста, 1996.- С. 5.

7. Манаенков А.С. Лесомелиорация арен засушливой зоны. - Волгоград: ВНИАЛМИ, 2014.$420 \mathrm{c.}$

8. Павловский Е.С., Петров В.И. Агролесомелиорация и адаптивное природопользование в аридной зоне // Лесомелиорация и ландшафт: сб. науч. тр. Волгоград, 1993. - Вып. 1(105). - С. 5-11.

9. Шардаков А.К., Эрдниев Е.П. Лесомелиоративное освоение полупустынных территорий Прикаспия // Вестник Алтайского госагроуниверситета. 2011. - № 3. - С. 86-91.
Халилов Шахвар Азимович, $\partial-p$ c. $-x$. наук, проф. кафедры «Техносферная безопасность и транспортнотехнологические машины», Саратовский государственный аграрный университет имени Н.И. Вавилова. Россия.

410056, г. Саратов, ул. Советская, 60.

Тел.: (8452) 74-96-35.

Шардаков Алибек Какимуллович, канд. с.-х. наук, доцент кафедры «Геоэкология и инженерная геология», Саратовский государственный технический университет имени Гагарина Ю.А. Россия.

410054, г. Саратов, ул. Политехническая, 77. Тел.: (8452) 74-96-65.

Ключевые слова: лесопастбищные угодья; энергия; агроэнергетический коэффиииент; продуктивность.

\title{
ECOLOGICAL OPTIMIZATION OF AGROLANDSCAPES IN THE DRY ZONE OF THE SOUTH-EAST IN RUSSIA
}

Khalilov Shakhvar Azimovich, Doctor of Agricultural Sciences, Professor of the chair "Technospheric Security and Transport-Technological Machines", Saratov State Agrarian University named after N.I. Vavilov. Russia

Shardakov Alibek Kakimullovich, Candidate of Agricultural Sciences, Professor of the chair "Gioecology and Engineering Geology”, Saratov State Technical University named after Gagarin Yu.A. Russia.

Keywords: sylvopastoral lands; energy; agroenergetic coefficient; productivity.
The presented article substantiates the technology of sustainable forest management of nature using ecologically safe methods, by creating small sylvopastoral systems. The general regularity of changes in the temperature of the surface layer of air and soil on nonreclaimed sylvopastoral lands is revealed. Calculations of the bioenergetic effect from forest reclamation works are given. The value of the sum of gross energy in the production of sylvopastoral land is determined, the coefficient of economic efficiency and the payback period are established.

DOI

удк 638.082; 577.2

\section{ВОСПРОИЗВОДИТЕЛЬНЫЕ КАЧЕСТВА КОРОВ В ЗАВИСИМОСТИ ОТ АЛЛЕЛЬНЫХ ВАРИАНТОВ ГЕНОВ КАППА-КАЗЕИНА И ДИАЦИЛГЛИЦЕРОЛ О-АЦИЛТРАНСФЕРАЗЫ}

\author{
ШАЙдУЛЛИН Радик Рафаилович, Казанский государственный аграрный университет \\ ШАРАФУТДИНОВ Газимзян Салимович, Казанский государственный аграрный университет \\ МОСКВИЧЕВА Анастасия Борисовна, Казанский государственный аграрный университет
}

Рассмотрена воспроизводительная способность высокопродуктивных коров с различными аллельными вариантами генов каппа-казеина и диацилглищерол О-ацилтрансферазы. Выявлено, что коровы с генотипом CSN3 ${ }^{A A}$, CSN3 $^{A B}$ и DGAT1 ${ }^{\text {кК }}$ имеют продолжительные сервис- и межотельный периоды и менъшие показатели коэффициента воспроизводительной способности и индекса плодовитости, что свидетельствует о некотором снижении их воспроизводительных качеств.

Введение. В животноводстве получение молока зависит не только от уровня молочной продуктивности, но и от воспроизводительной способности коров. К тому же воспроизводство является основным биологическим условием, регулирующим рост поголовья. При невысоких показателях воспроизводительной способности сдерживается темп роста стада. Также от состояния и уровня воспроизводства зависит эффективность селекционно-племенной работы, продолжительность продуктивного долголетия высокопродуктивных животных и качество получаемой животноводческой продукции $[3,6,8,10]$. Следовательно, кроме повышения молочной продуктивности необходимо улучшать воспроизводительные качества молочного скота.

Изучению воспроизводительной способности коров в зависимости от разных генотипов маркерных генов посвящены работы некоторых отечественных ученых $[1,2,4,7,9]$. Полученные ими результаты несколько противоречивы и позволяют сделать вывод, что для каждого отдельного стада они могут быть различными, на что влияет множество генетических и паратипических факторов - порода, уровень удоя, условия кормления и содержания. При этом исследователи констатируют, что нет четкого отрицательного влияния генотипа животных по аллельным 
вариантам маркерных генов на их воспроизводительные качества. В то же время выявлено, что коровы с генотипом AА по гену каппа-казеина и AА по гену диацилглицерол О-ацилтрансферазы имеют преимущество по воспроизводительным качествам [5, 11].

Цель нашей работы - изучение влияния различных аллельных вариантов маркерных генов на воспроизводительные качества молочного скота.

Методика исследований. Объектом исследования служили высокопродуктивные коровы черно-пестрой породы, имеющие удой более 5000 кг, с различным генотипом по гену каппаказеина (CSN3) и диацилглицерол О-ацилтрансферазы (DGAT1), принадлежащие ООО «Дусым» Атнинского р-на Республики Татарстан.

Для исследований были взяты пробы венозной крови опытных коров. Изучение однонуклеотидного полиморфизма генов CSN3 и DGAT1 проводили в ФГБНУ «Федеральный центр токсикологической, радиационной и биологической безопасности». ДНК из венозной крови выделяли стандартным методом с помощью набора «Магносорб» (Интерлабсервис, г. Москва). Аллельные варианты генов каппа-казеина и диацилглицерол О-ацилтрансферазы определяли методом полимеразной цепной реакции с последующим анализом по полиморфизму длин рестрикационных фрагментов (ПЦР-ПДРФ) продуктов амплификации генов. ПЦР проводили на амплификаторе ДТ-96. Продукт ПЦР оценивали горизонтальным электрофорезом в 2,5\%-м агарозном геле, окрашенном бромистым этидием.

По результатам ДНК-тестирования коровы были распределены по группам в зависимости от генотипа. По гену CSN3: CSN3 ${ }^{\mathrm{AA}}$ - 115 гол., $\mathrm{CSN}^{\mathrm{AB}}$ - 84 гол., CSN3 ${ }^{\mathrm{BB}}$ - 9 гол.; по гену DGAT1: DGAT1 ${ }^{\mathrm{AA}}$ - 89 гол., DGAT1 ${ }^{\text {АК }}$ - 105 гол., DGAT1 ${ }^{\text {кK }}-14$ гол. Также были изучены комплексные генотипы животных одновременно по двум генам CSN3 и DGAT1.

Воспроизводительные качества животных изучали по показателям, характеризующим плодовитость коров, - возраст первого отела, длительность сервис-периода и межотельного периода (МОП), коэффициент воспроизводительной способности (КВС), индекс плодовитости (по Дохи).

Результаты исследований. Проведенные исследования позволили установить, что по возрасту первого отела высокопродуктивные коровы с аллельным вариантом гена каппа-казеина ВB характеризуются наибольшими показатели $(28,7$ мес.) по сравнению с аналогами (табл. 1). При этом разность статистически достоверна между группами животных с генотипом CSN3 ${ }^{\mathrm{AB}}$ и CSN3 $3^{\mathrm{AA}}$ на 0,5 мес. $(P<0,01)$. Также гомозиготные коровы по аллелю В каппа-казеина имеют удлиненные сервис- и межотельный периоды (115 и 403 дня).
Таблица 1

Воспроизводительная способность коров с разными аллельными вариантами гена каппа-казеина

\begin{tabular}{|l|c|c|c|}
\hline \multirow{2}{*}{\multicolumn{1}{|c|}{ Показатель }} & \multicolumn{3}{c|}{ Генотип по CSN3 } \\
\cline { 2 - 4 } & $\mathrm{AA}$ & $\mathrm{AB}$ & $\mathrm{BB}$ \\
\hline$n$ & 115 & 84 & 9 \\
\hline $\begin{array}{l}\text { Возраст первого } \\
\text { отела, мес. }\end{array}$ & $27,8 \pm 0,14$ & $28,3 \pm 0,13$ & $28,7 \pm 0,55$ \\
\hline Сервис-период, дней & $111 \pm 1,8$ & $113 \pm 2,3$ & $115 \pm 4,6$ \\
\hline $\begin{array}{l}\text { Межотельный период, } \\
\text { дней }\end{array}$ & $394 \pm 2,1$ & $400 \pm 2,6$ & $403 \pm 4,2$ \\
\hline $\begin{array}{l}\text { Коэффициент } \\
\text { воспроизводительной } \\
\text { способности }\end{array}$ & $0,93 \pm 0,004$ & $0,91 \pm 0,006$ & $0,91 \pm 0,01$ \\
\hline Индекс Дохи & $46,2 \pm 0,24$ & $45,4 \pm 0,20$ & $44,8 \pm 0,77$ \\
\hline
\end{tabular}

Лучшие показатели коэффициента воспроизводительной способности $(0,93)$ и индекса плодовитости $(46,2)$ выявлены у коров с генотипом $\mathrm{CSN}^{\mathrm{AA}}$, при достоверном преимуществе над животными с генотипом CSN3 ${ }^{\mathrm{AB}}$ - на $0,02(P<0,01)$ и $0,8(P<0,05)$ соответственно, а над группой $\mathrm{CSN}^{\mathrm{BB}}$ только по коэффициенту воспроизводительной способности на $0,02(P<0,05)$.

По гену диацилглицерол О-ацилтрансферазы высокопродуктивные коровы с генотипом DGAT1 ${ }^{\text {AK }}$ имеют высокие значения возраста первого отела (27,9 мес.), длительности сервис-периода (114 дней), межотельного периода (399 дней) и превышают по вышеназванным показателям гомозиготных особей с генотипом DGAT1 ${ }^{\text {КК }}$ на 0,3, 5 и 2 дня соответственно (табл. 2).

Таблица 2

Воспроизводительная способность коров с разными аллельными вариантами гена диацилглицерол 0-ацилтрансферазы

\begin{tabular}{|l|c|c|c|}
\hline \multirow{2}{*}{\multicolumn{1}{|c|}{ Показатель }} & \multicolumn{3}{|c|}{ Генотип по DGAT1 } \\
\cline { 2 - 4 } & АA & АК & КК \\
\hline$n$ & 89 & 105 & 14 \\
\hline $\begin{array}{l}\text { Возраст первого } \\
\text { отела, мес. }\end{array}$ & $27,9 \pm 0,17$ & $28,2 \pm 0,15$ & $27,6 \pm 0,48$ \\
\hline Сервис-период, дней & $114 \pm 2,1$ & $111 \pm 1,7$ & $109 \pm 4,3$ \\
\hline $\begin{array}{l}\text { Межотельный период, } \\
\text { дней }\end{array}$ & $399 \pm 2,3$ & $396 \pm 2,0$ & $397 \pm 5,5$ \\
\hline $\begin{array}{l}\text { Коэффициент } \\
\text { воспроизводительной } \\
\text { способности }\end{array}$ & $0,91 \pm 0,005$ & $0,92 \pm 0,004$ & $0,92 \pm 0,013$ \\
\hline Индекс Дохи & $45,8 \pm 0,27$ & $45,7 \pm 0,23$ & $46,3 \pm 0,68$ \\
\hline
\end{tabular}

Лучшие значения коэффициента воспроизводительной способности $(0,92)$ и индекса плодовитости $(46,3)$ характерны для коров с генотипом DGAT1 ${ }^{\text {кк, }}$ при преимуществе над остальными группами на 0,01 и 0,5-0,6. При изучении воспроизводительной способности высокопродуктивных коров с разными комбинациями генотипов каппа-казеина и диацилглицерол О-ацилтрансферазы установлена меньшая длительность сервис- и межотельного периодов у животных с генотипом CSN3 ${ }^{\mathrm{AA}}$ / DGAT1 $^{\mathrm{AK}}$ (106 дней) и $\mathrm{CSN}^{\mathrm{AA}} / \mathrm{DGAT}^{\text {КК }}$ (105 дней) (табл. 3). Коровы с генотипом CSN3 ${ }^{\mathrm{AA}} / \mathrm{DGAT}^{\mathrm{AK}}$ имеют достоверноепреимущество по коэффициенту 
воспроизводительной способности над животными с генотипом CSN3 ${ }^{\mathrm{AB}} / \mathrm{DGAT}^{\mathrm{AA}}, \mathrm{CSN} 3^{\mathrm{AB}}$ / DGAT1 $^{\mathrm{AK}}$, $\mathrm{CSN}^{\mathrm{BB}} / \mathrm{DGAT}^{\mathrm{AK}}$ на $0,03(P<0,05)$.

Таблица 3

Воспроизводительная способность коров с разными комбинациями генотипов CSN3/DGAT1

\begin{tabular}{|c|c|c|c|c|c|}
\hline $\begin{array}{c}\text { Генотип } \\
\text { по CSN3 / } \\
\text { DGAT1 }\end{array}$ & $\begin{array}{c}\text { Возраст } \\
\text { первого } \\
\text { отела, мес. }\end{array}$ & $\begin{array}{c}\text { Сервис- } \\
\text { период, } \\
\text { дней }\end{array}$ & $\begin{array}{c}\text { МОП, } \\
\text { дней }\end{array}$ & КВС & $\begin{array}{c}\text { Индекс } \\
\text { Дохи }\end{array}$ \\
\hline $\mathrm{AA} / \mathrm{AA}$ & $27,9 \pm 0,18$ & $114 \pm 2,3$ & $398 \pm 2,6$ & $0,92 \pm 0,01$ & $45,9 \pm 0,30$ \\
\hline $\mathrm{AA} / \mathrm{AK}$ & $27,7 \pm 0,27$ & $106 \pm 3,1$ & $388 \pm 3,6$ & $0,94 \pm 0,01$ & $46,8 \pm 0,40$ \\
\hline $\mathrm{AA} / \mathrm{KK}$ & $27,6 \pm 0,40$ & $105 \pm 5,2$ & $389 \pm 6,7$ & $0,94 \pm 0,02$ & $46,8 \pm 0,71$ \\
\hline $\mathrm{AB} / \mathrm{AA}$ & $27,6 \pm 0,47$ & $112 \pm 3,1$ & $403 \pm 4,0$ & $0,91 \pm 0,01$ & $45,9 \pm 0,53$ \\
\hline $\mathrm{AB} / \mathrm{AK}$ & $28,5 \pm 0,18$ & $113 \pm 2,2$ & $400 \pm 2,5$ & $0,91 \pm 0,01$ & $45,2 \pm 0,27$ \\
\hline $\mathrm{AB} / \mathrm{KK}$ & $27,2 \pm 0,75$ & $110 \pm 6,8$ & $398 \pm 8,1$ & $0,92 \pm 0,02$ & $46,6 \pm 1,01$ \\
\hline $\mathrm{BB} / \mathrm{AK}$ & $28,1 \pm 0,55$ & $111 \pm 5,2$ & $400 \pm 4,5$ & $0,91 \pm 0,01$ & $45,5 \pm 0,82$ \\
\hline
\end{tabular}

У исследуемых высокопродуктивных коров индекс Дохи колебался от 45,2 у генотипа CSN3 ${ }^{\mathrm{AB}} /$ DGAT1 $^{\mathrm{AK}}$ до 46,8 у генотипа CSN3 ${ }^{\mathrm{AA}} /$ DGAT1 $^{\text {AK }}$ с генотипом CSN3 $^{\mathrm{AA}}$ / DGAT1 ${ }^{\mathrm{A \kappa}}$, при этом разность между данными группами животных составила 1,6 и была статистически достоверна $(P<0,01)$.

Заключение. В ходе исследований установлено, что лучшие показатели воспроизводительной способности имеют высокопродуктивные коровы с генотипом CSN3 ${ }^{\mathrm{AA}}$ и CSN3 ${ }^{\mathrm{AB}}$. Оптимальные показатели воспроизводительной способности выявлены у коров с генотипом DGAT $1^{\text {кK. }}$

Высокие значения длительности сервис- и межотельного периодов и меньшие показатели коэффициента воспроизводительной способности и индекса Дохи у коров, несущих в своем геноме В аллель гена каппа-казеина и А аллель гена диацилглицерол О-ацилтрансферазы, свидетельствуют о незначительном снижении воспроизводительной способности животных.

\section{СПИСОК ЛИТЕРАТУРЫ}

1. Алипанах M. Хозяйственно-полезные признаки крупного рогатого скота с различными генотипами каппа-казеина и пролактина: автореф. дис. ... канд. с.-х. наук. - М., 2006. - 19 с.

2. Ахметов Т.М., Тюлькин С.В., Валиуллина Э.Ф. Молочная продуктивность и воспроизводительная способность голштинизированных коров в зависимости от генотипа каппа-казеина // Ветеринарный врач. - 2007. - № 4. - С. 58-61.

3. Бальианов А.И., Рыжова Н.Г., Сидякин А.И. Влияние генетических факторов на воспроизводительную способность коров создаваемого поволжско- го типа // Инновационные разработки молодых ученых - АПК России: материалы Всерос. науч.-практ. конф. молодых ученых, посвящ. памяти Р.Г. Гареева. - Казань: Фолиантъ, 2010. - С. 341-346.

4. Баршинова А.В. Полиморфизм гена каппа-казеина и его связь с хозяйственно-полезными признаками скота красно-пестрой породы: автореф. дис. ... канд. биол. наук. - Лесные Поляны, 2005. - 22 с.

5. Ганиев А.С., Шайдуллин Р.Р., Сибагатуллин Ф.С. Воспроизводительная способность коров с разными генотипами молочных генов // Вестник Казанского государственного аграрного университета. - 2015. № 2 (36). - C. 101-104.

6. Голикова А.П., Федосеева Н.А. Воспроизводительная функция коров и ее экономическое значение // Вестник Российского государственного аграрного заочного университета. - М., 2006. - С. 114-118.

7. Грашин А.А. Влияние генотипов каппа-казеина на хозяйственно-полезные признаки скота самарского типа черно-пестрой породы: автореф. дис. ... канд. биол. наук. - Лесные Поляны, 2011. - 21 с.

8. Карабаева М.Э., Гриняева Ю.Г. Повышение молочной продуктивности коров // Аграрный научный журнал. - 2015. - № 9. - С. 19-21.

9. Покусай О.Е. Влияние различных генотипов каппа-казеина и бета-лактоглобулина на воспроизводительные качества первотелок черно-пестрой породы // Зоотехния. - 2011. - № 10. - С. 31-32.

10. Сидякин А.И. Оценка коров создаваемого поволжского типа красно-пестрой породы по репродуктивным качествам: автореф. дис... канд. с.-х. наук. Лесные Поляны, 2010. - 19 с.

11. Шайдуллин Р.Р., Юльметьева Ю.Р., Шарафутдинов Г.С. Воспроизводительные качества коров разных генотипов // Землеустройство - основа рационального использования земельных ресурсов: сб. науч. тр. - Казань, 2017. - С. 95-99.

Шайдуллин Радик Рафаилович, канд. с.-х. наук, доцент, зав. кафедрой «Биотехнология, животноводство и химия», Казанский государственный аграрный университет. Россия.

Шарафутдинов Газимзян Салимович, $\partial-p c .-x$. наук, проф. кафедры «Биотехнология, животноводство и химия», Казанский государственный аграрный университет. Россия.

Москвичева Анастасия Борисовна, канд. с.-х. наук, доцент кафедры «Биотехнология, животноводство и химия», Казанский государственный аграрный университет. Россия.

420015, г. Казань, ул. К. Маркса, д. 65.

Тел.: (843) 567-45-00.

Ключевые слова: воспроизводительная способность; коровы; генотип; CSN3; DGAT1.

\section{REPRODUCTIVE QUALITY OF COWS DEPENDING ON ALLELLIC VARIANTS OF KAPPA CASEIN GENES AND DGAT}

Shaydullin Radik Rafailovich, Candidate of Agricultural sciences, Associate Professor, Head of the chair "Biotechnology, Livestock and Chemistry", Kazan State Agrarian University. Russia.

Sharafutdinov Gazimzyan Salimovich, Doctor of Agricultural Sciences, Professor of the chair "Biotechnology, Livestock and Chemistry", Kazan State Agrarian University. Russia.

Moskvicheva Anastasia Borisovna, Candidate of Agricultural sciences, Associate Professor of the chair "Biotechnology, Livestock and Chemistry”, Kazan State Agrarian University. Russia.
Keywords: reproductive ability; cows; genotype; CSN3; DGAT1.

The reproductive ability of highly productive cows with different allelic variants of kappa casein and DGAT. It was revealed that cows with the genotype CSN3AA, CSN3AB and DGAT1KK have a long service and calving intervals and lower indicators of the reproductive and fertility index, which indicates a certain decrease in their reproductive qualities. 